\title{
Eschatology as a manifestation of human uniqueness: Human vision, biblical revelation and divine agency

\begin{abstract}
Author:
Klaus B. Nürnberger

Affiliation:

${ }^{1}$ Department Dogmatics and Christian Ethics, Faculty of Theology, University of Pretoria, South Africa

Research Project Registration:

Project Leader: J. Buitendag Project Number: 02402343

\section{Description:}

Prof. Dr Klaus Nürnberger is part of the research project, 'Theology of Nature', directed by Prof. Dr Johan Buitendag (Dean, Faculty of Theology), Department Dogmatics and Christian Ethics, Faculty of Theology, University of Pretoria.
\end{abstract}

\section{Corresponding author:}

Klaus Nürnberger,

nurnberger@telkomsa.net

Dates:

Received: 11 Oct. 2016

Accepted: 01 May 2017

Published: 08 Dec. 2017

How to cite this article: Nürnberger, K.B., 2017,

'Eschatology as a manifestation of human uniqueness: Human vision, biblical revelation and divine agency', HTS Teologiese Studies/Theological Studies 73(3), a4341. https://doi. org/10.4102/hts.v73i3.4341

\section{Copyright:}

(c) 2017. The Authors.

Licensee: AOSIS. This work is licensed under the Creative Commons Attribution License.

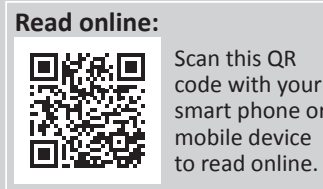

\begin{abstract}
This essay extends my previous research on eschatology to cover the question of human uniqueness. Using the approach of 'experiential realism', I begin with a few findings of modern science that are relevant to the topic: big bang cosmology, entropy, regularity and contingency, and emergence theory. On this basis, I discuss human uniqueness at the physical, biological and consciousness levels. There is indeed continuity between humans and other living beings, yet humans are far ahead of other creatures on an exponentially accelerating trajectory. Part of human consciousness is the capacity to envision the future. It can confine itself to what is possible and probable, or overshoot these limitations. I discuss three ways human beings experience time: physical, experiential and existential. The latter projects a vision of what ought to become as a response to the experience of what ought not to have become. A vision of what ought to become implies criteria and an ultimate authority setting such criteria. Against this background, I analyse the evolution of biblical future expectations. Apocalyptic eschatology and resurrection of the dead are the most radical among many other, and more mundane future expectations. They emerged late in postexilic Judaism, were never generally accepted and began to lose their plausibility and relevance in New Testament times already. While projections that overshoot the given are immensely important for human life in general and the Christian faith in particular, apocalyptic eschatology envisages the replacement of the existing world with a perfect world, rather than its transformation. This can lead to pious fatalism and despondency and thus become counterproductive. The theological defence of apocalyptic eschatology rests on various untested assumptions. I briefly discuss and critique the concepts of divine agency, omnipotence, eternity and contingency. Finally, I propose a reconceptualisation of Christian future expectations as human participation in God's vision of comprehensive optimal well-being, which translates into God's concern for any deficiency in wellbeing in any aspect of life and which operates like a horizon that moves on as we approach it, opening up ever new vistas, challenges and opportunities.
\end{abstract}

\section{Introduction}

Eschatology is one of the most intractable issues in the encounter between science and theology. ${ }^{1}$ Among theologians, eschatology is widely regarded as the centre of the Christian faith, ${ }^{2}$ while modern scientific insights profoundly question the certainties of conventional eschatology. The law of entropy precludes the emergence of a universe without the constraints of time, space, energy and regularity ${ }^{3}$ and the theory of emergence precludes the 'resurrection' of a person 'released' from its physical and biological infrastructure.

The impasse can hardly be resolved if believers base their certainties on what they consider to be an eternally valid 'divine revelation' contained in the Holy Scriptures, while the practical sciences follow the method of 'experiential realism'. ${ }^{4}$ Sensing the incongruence, leading European \footnotetext{
1.Robert John Russell drew attention both to the fact that, in contrast to creation and big bang cosmology, the challenge raised by science
to eschatology 'has received, with only a few exceptions, strikingly little sustained attention' as well as the fact that those who did raise to eschatology 'has received, with only a few exceptions, strikingly little sustained attention' as well as the fact that those who did raise
the issue came to rather dismal conclusions: Ted Peters wrote that if the forecast of the law of entropy came to pass, 'we would have proof that our faith has been in vain. It would turn out to be that there is no God, at least not the God in whom followers of Jesus have put their faith'. And John Macquarrie: ' $[I f]$ it were shown that the universe is indeed headed for an all-enveloping death, then this might ... falsify Christian faith and abolish Christian hope' (Russell 2008:298-299). Taking these concerns seriously, Russell tried to rescue conventional eschatology with a series of rather adventurous scientific assumptions. See my response to Russell in Nürnberger (2012:970-996).
}

2.According to the earliest sources, Jesus announced the immediate proximity of the Kingdom of God (Mark 1:14). Paul stated categorically that doubting the resurrection of the body would render the Christian gospel meaningless and the Christian faith sham (1 Cor 15:12-19). These texts alone are so intimidating for Bible-centred theologians and believers that few dare to ask whether the intended message can be translated from apocalyptic into alternative worldview assumptions.

\section{Peters describes the dissonance in stark terms (Peters, Russell \& Welker 2002:x)}

4.Experiential realism is akin to 'critical realism' (e.g. Peacocke 2007:10) and 'model-dependent realism' (Hawking \& Mlodinow 2010:7). It is called realism because, in contrast to epistemological and postmodern scepticism, it trusts that our perceptions of reality, while problematic as mental constructs, are sufficiently reliable to give us an impression of objective reality and lead us through life on that basis. It is called experiential, rather than empirical, because, based on the theory of emergence, it includes all levels of experience, including those of consciousness, in its concept of reality and not only the quantum, physical-chemical and biological levels. 
continental theologians of the 20th century reinterpreted eschatology fairly consistently in a way that avoids the crass statements of classical (apocalyptic) eschatology. The same is true for newer worldwide trends:

They 'have redefined eschatology in such a way that the "last things" at the end of world history have become the "decisive things" in the midst of our present experience. It is the crisis of our lives and our life worlds emanating from God's revelation as Lord, Judge and Creator coming "vertically from above" (Barth); it is an "axiological" (= value based), rather than a historically based set of propositions (the early Paul Althaus); it is a symbolic answer to the question of the meaning of history as a criterion of whatever happened and will happen (Paul Tillich); it is the authentic self, constituted by the gift of God rather than by our achievement (Bultmann); it is the vision of a radically new future based on the resurrection of Christ that transcends every present and motivates us to go beyond what seems likely and possible (Moltmann); it is an anticipation of the ultimate consummation of world history, pre-shadowed in the Christ-event (Pannenberg); it is a new world order based on justice for the poor and oppressed (liberation theology); it is the advent of a more humble, open and humane collective spirit (postmodernism). All these phenomena can be called "eschatological" or "the Kingdom of God" in the sense of "ultimate" or "foundational". (Nürnberger 2016: vol. II, 473-474)

However, conventional eschatological convictions linger on in quarters that take biblical statements and classical doctrines as revealed, authoritative truth that cannot be questioned. These assumptions cause uncertainty, desperate attempts to rescue what is deemed biblical revelation in the face of scientific findings and, as I perceive it, spiritual dishonesty.

In this essay, I presuppose my often expressed contention that theology should adopt the approach of experiential realism for its own work and take valid scientific insights on board as far as immanent reality is concerned. This would enable us to conceptualise the intended thrust of the biblical messages more appropriately and restore the credibility of this message among an audience informed by modern science. $^{5}$

Experiential realism confines itself to immanent reality, that is, the realm accessible, at least in principle, to human observation, explanation and manipulation. ${ }^{6}$ It avoids deductions from untested assumptions, whether based on metaphysical constructs or reified biblical metaphors. ${ }^{7}$ This does not mean that theology should give up on faith in God! If God is the transcendent Source and Destiny of reality, 'he' makes himself known to us through 'his' creation, that is, the world we experience and the sciences explore, including the human spiritual capacity of intuiting and conceptualising the divine.

\section{See Nürnberger (2013) for a programmatic discussion of this approach.}

6.It is true that 'the natural has become, more or less, an intangible construct of science, far removed from our intuitive experience of nature'. However, when scientific discoveries (rather than mathematical constructs) become common knowledge, they also become part of the interpretation of experienced reality: we knowledge, they also become part of the interpretation of experie

7.For a full discussion of the approach of experiential realism, see Nürnberger 2016:47-55.
This essay is meant to link my previous work on eschatology with the concept of human uniqueness. ${ }^{8}$ I begin with a few scientific insights and the concept of God that follow from the approach of experiential realism. After a reflection on human uniqueness, including the human experience of time and the capacity to envision a more acceptable future, I highlight the experiential nature of biblical future expectations including the apocalyptic 'overshoot'.

Then a few concepts associated with eschatology are critiqued: divine agency, omnipotence, eternity and contingency. I close with a suggestion of how experiential realism can enable us to express the concern hidden in prescientific future expectations in a way that is theologically valid, plausible in experiential terms and motivating for us today.

\section{To begin with a few relevant worldview assumptions}

Following the approach of experiential realism, I assume the validity of the following scientific worldview assumptions: ${ }^{9}$

- Big bang cosmology implies that there is only one immanent reality, that is, a reality accessible at least in principle to human observation, explanation and prediction. It also implies that this reality has come about and is sustained through an all-encompassing evolutionary process.

In contrast to a naturalistic metaphysics, however, this assumption does not preclude the intuition or notion that immanent reality is open towards a transcendent Source and Destiny, rather than closed in upon itself. The experiential basis of this intuition is our consciousness of being derived, embedded, dependent, vulnerable, mortal, accountable and culpable - all of which imply a higher authority that constitutes our existence and the existence of our life world.

- The law of entropy: According to this law, energy conglomerations tend to move from potent energy to spent energy, from hot to cold, from order to disorder, from compaction to dissipation, from situations far from equilibrium towards equilibrium. ${ }^{10}$ It also suggests that the energy necessary for evolutionary construction is derived from entropic deconstruction elsewhere in the system. ${ }^{11}$

- Regularity and contingency: That the cosmic process follows distinct regularities (laws of nature) is self-evident.

8.The essay was first conceived as a contribution to the meeting of the European Society for the Study of Science and Theology on the topic of human uniqueness in Society for the Study of Science and Theology
2015 , which I was not able to attend after all.

9.For an excellent, more elaborate yet concise summary of current scientific worldview assumptions, see Barrett 2015:29-36. Note, however, that I would not be able to follow him in his theological approach.

10.The law of entropy was first formulated as the second law of thermodynamics. However, it has since been applied very appropriately in many other academic disciplines: the escalating discrepancies between economic centres and peripheries, the ecological fallout of economic development, the invasion of alien plants in certain environmental niches, political power concentrations, dominant worldviews and ideologies, even to competing convictions: any new conviction
goes at the expense of the old.

11.In thermodynamics, this is only valid for closed systems. The earth, for instance, is an open system that can import potent energy from the sun. However, considering a wider horizon, this goes at the expense of the energy of the sun! 
However, states do occur that are contingent, that is, underdetermined, perhaps even undetermined. The latter are states where the forces impacting a situation are so finely balanced that the process can move in any direction. A needle standing precisely on its head will stand upright forever if no other force is introduced into the situation. The slightest outside impact will determine the further direction of the process, a phenomenon that is called 'sensitivity to initial conditions' in chaos theory.

At the Newtonian level, such ideal situations do not occur very frequently, if at all. If they do occur, they are extremely unstable. In contrast, situations with moderate imbalances between powers that can be modified through the introduction of additional powers are frequent, and in fact ubiquitous. Agency becomes possible in such situations of contingency, that is, in undetermined or underdetermined situations, albeit only within the parameters set by past developments that have led to the present situation.

Depending on the forces that impact the current situation, the parameters determined by the past open up a considerable, yet limited spectrum of possibilities: the actualising possible, the adjacent possible, various stages of a more remote possible and leading right up to the impossible. ${ }^{12}$ Moreover, contingency becomes exponentially more frequent and wider in scope the higher we move on the hierarchy of emergences, ${ }^{13}$ eventually opening up the space for what we call the 'freedom of the will'..$^{14}$

- The theory of emergence: Cosmic evolution progresses in exponentially rising levels of complexity, flexibility and differentiation (Clayton 2006:2-7, 60-62; Kauffman 1995:23-28; Peacocke 2007:12-16). This process is due to the fact that networks of relationships constitute wholes with characteristics that cannot be reduced to those of their components. Every subsequent level of emergence is, therefore, more than the sum total of its components and follows its own regularities and contingencies.

Seen in this light, cosmic evolution covers the entire hierarchy of emergences from subatomic phenomena to spiritual and social constructs. By implication, intuitions and notions of God - and of eschatological consummation for that matter are part of cosmic evolution, only at a level of emergence higher than the physical and biological levels. Figure 1 offers a crude summary of some of the more important levels of emergence.

12.Kauffman (2015:13-16 and previous work) uses the term 'adjacent possible' fo the next possible step in the evolutionary and emergent sequence of potentialities, while I am using the term for what could have become reality if the powers that impacted a situation had been slightly different. The two meanings complement rather than exclude each other.

13.Note Kauffman's persuasive argument that from the biological level onward processes become not only unpredictable but in some sense void of regularity (2015:10-16).

14.By implication, freedom of the will, often disputed by a reductionist view of causality, is not only a necessary postulate, but a demonstrable fact. However, it is always a constrained freedom. While I can move about freely in a room, I cannot move through a wall. Employing greater forces (e.g. a bulldozer) I can move move through a wall. Employing greater forces (e.g. a bulldozer) I can move
through the wall, but I cannot move down to the core of the earth. For an in-depth discussion, see Nürnberger (2016:146-149).

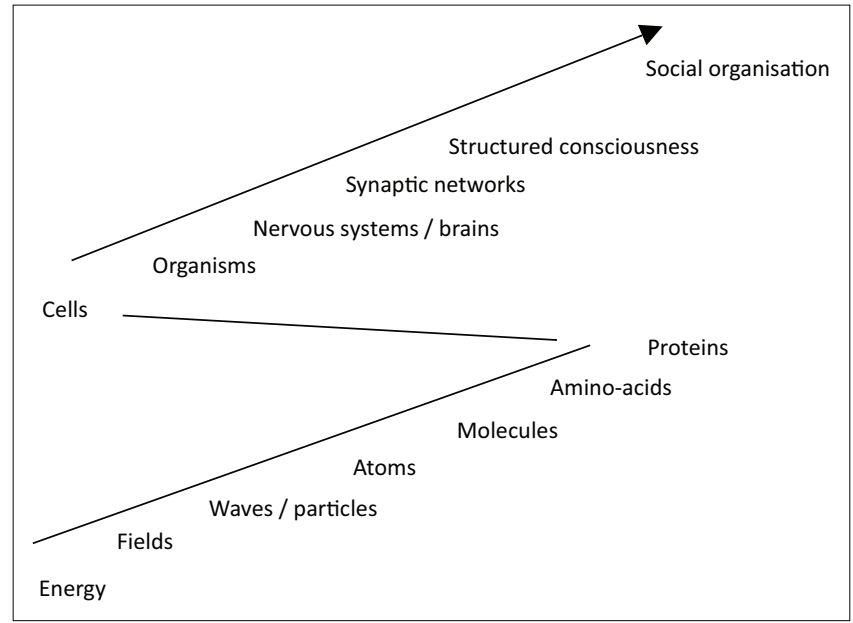

FIGURE 1: Levels of emergence.

\section{An experiential concept of God}

In experiential terms, faith is built on the underlying intuition or notion that reality is not closed in upon itself, as naturalism has it, but open towards a transcendent Source and Destiny with whom it is possible to communicate on personal terms.

As mentioned above, this intuition is based on the consciousness of being derived, embedded, dependent, vulnerable, mortal, accountable and culpable - all of which imply some higher authority that constitutes our existence and the existence of our life worlds.

But that is only the formal framework; it is the content that matters. It can be profound or shallow, liberating or enslaving, motivating or intimidating, sensitising or brutalising, legitimating our autonomy or calling us into responsibility. Everything in theology, including our assessment of eschatology, depends on how precisely the notion of God is conceived.

The critical point of a Christian experiential concept of God is that we identify God's creative activity with the world that we actually experience and that the sciences explore, and God's redemptive benevolence with what this reality ought to become and could become. ${ }^{15}$ Let us begin with a few basic parameters of an experiential concept of God:

- 'God' is our name for the intuited, proclaimed and believed transcendent Source and Destiny of reality - precisely the reality that we experience and that the sciences explore. 'Source and Destiny' are not meant to denote a sequence in time with a specified beginning and an inevitable outcome, but the dynamic that drives reality (Source) and the intentionality that motivates that thrust (Destiny). ${ }^{16}$

15. Friedrich Nietzsche, an incisive critic of the Christian faith in the 19th century, declared the God concept of the theological tradition dead when Hegelian idealism began to crack up in the second half of the 19th century. After World War I, perceptive theologians, such as Friedrich Gogarten and Dietrich Bonhoeffer, followed by death-of-God theologies, recognised that modern secular humanity has no use for such a concept of God and that in spite of the bold postulates of Kar Barth that God is real for us only in his self-revelation as our sovereign Lord revealing our notions of God as self-justification and idolatry. For this development, see Zahrnt (1966 [1969]:chapters 1 and 5).

16. Cosmic evolution is a manifestation of God's creative power, but it is not identical with God 'himself', whether in terms of pantheistic or panentheistic assumptions. Only if the cosmic process is not ultimate, thus divine, but the creation of God, can we participate in God's freedom and God's power, and thus become spiritually free we participate in God's freedom and God's power, and thus
from the world and, at the same time, free for the world. 
Being embedded in, and thus confined to, immanent reality, we can have no knowledge of the transcendent God other than God's creative power, which is identical with the evolving cosmic process that we experience and that the sciences explore, and God's benevolent intentionality, which is proclaimed and believed on the basis of the biblical tradition that culminated in the Christ-event and that is part of the evolving cosmic process at the spiritual level of emergence. ${ }^{17}$

While cosmic evolution is a manifestation of God's creative power, God is not a factor within experienced reality, which could cooperate or compete with other such factors, albeit a 'supernatural' factor, but the Source and Destiny of all these factors. God operates in and through immanent reality. Divine action does not obviate human actions and natural events but initiates and empowers them - even at the level of an active faith (Phil 2:12-13). ${ }^{18}$ Therefore, it is inappropriate to say that God 'intervenes' at certain junctures and not in others, as if he were not the Source of the entire process.

It is also inappropriate to assume that God's action, at whatever level of emergence, is unmediated by immanent reality. God's creative power operates through evolutionary processes and God reveals his redeeming love through human communication, attitude and action. There is no word of God that is not a human word and, being human, it is historically and situationally relative, susceptible to error and subject to critique:

- 'God as such' is transcendent. That means that God is not accessible to our observation, explanation or manipulation and cannot be. Faith and theology are dealing with intuitions, notions or concepts of God based on actual faith experiences, rather than with metaphysical speculations about God as such.

Contrary to the reductionist assumptions of crude empiricism, such intuitions, notions or concepts must be taken seriously as part of experienced reality because they emerge and evolve in history, have concrete and far-reaching consequences in this world and are based on synaptic networks in our brains.

If God has indeed revealed 'himself' to human beings, as we believers assume, 'he' has revealed 'himself' through such intuitions and notions and concepts, otherwise this revelation would not have reached us. Again, there is no divine revelation that is not mediated through human consciousness, and thus subject to historical and situational variation and human error.

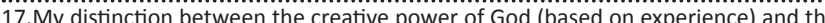
redemptive intentionality creative power of God (based on experience) and the metaphysical duntionality of God (based on proclamation) does not reflect powerful and loving God. As Christians, we cannot avoid the ambiguity of reality, which we attribute to the Creator, and the reassurance of the benevolent intentions of this same God.

18.This vertical rather than horizontal relationship between divine and human subject is fully recognised in classical Christology. The Council of Chalcedon (451) insisted the full divinity and the full humanity of the Christ-event. The on the full divinity and the full humanity of the Christ-event. The two levels should neither be confused with each other nor separal of ( the divine will and the human will operating in Christ. Both doctrines explicitly exclude a middle way between the full divinity and the full humanity of Christ, which would imply that Christ was either a half-god or a super-man.
Believers are persuaded that God uses God's creation (in this case the brain power of humans) to make God's creative power and God's benevolent intentionality known to us, albeit in a broken form that must always be subjected to scrutiny and reconceptualisation. Theology is all about the appropriateness and adequacy of such a notion of God.

This implies some kind of criterion. In biblical terms, the criterion of an appropriate conceptualisation of God is the dialectic between God's (experienced) creative power and God's (proclaimed) benevolent intentionality. This concept of God emerged and evolved as a religious tradition in ancient Israel, culminating in the Christ-event. Obviously, other convictions have other concepts of the transcendent:

- Cosmic evolution is the best explanatory model for reality available at present. The evolutionary process as such and as a whole is identical with the creative activity of God. Concerning the way reality emerged, evolved and functions, there is no way ancient biblical texts or classical doctrinal formulations can compete or cooperate with the insights of modern science. Theology has its own contribution to make in a dimension of life about which the sciences have nothing to say, namely God's comprehensive vision and redeeming love for precisely this universe. ${ }^{19}$

- Cosmic evolution is driven by energy constellations that follow certain regularities and contingencies in space and time. It is imperative that we perceive God's creative activity in terms of the regularities as much as in terms of the contingencies. God does not need contingency to act creatively, as some theologians seem to believe, but acts creatively precisely through structures and processes that follow certain regularities. ${ }^{20}$

- If God is the Source of the very reality that we experience and the sciences explore, God is the Source of the entropic process as much as of the evolutionary process because one cannot function without the other. According to the biblical tradition, God builds up and dismantles; gives life and takes life; empowers and disempowers; hardens hearts and renews hearts. Biblical faith does not believe in two gods, one good and one evil, as the ancient Persians did. ${ }^{21}$

19.The idea that science and theology operate at the same level of ontology, validity and dignity determines wide sections of the science-religion interface, whether as
meeting in the middle of the Golden Gate bridge (Russell 2008:1), a common meeting in the middle of the Golden Gate bridge (Russell 2008.1), a common rationality making a transversal dialogue possible (van Huyssteen 2006) or doctrinal positivism competing with science in finding 'truth' (Peters et al. 2002:xiii). In my view, this horizontal image confuses and jeopardises rather than
enhances mutual understanding.

20.If we say that the evolutionary process is autonomous and functions without the action of God, we betray a Deistic concept of God. If we then say that God intervenes in this process at certain instances, we are busy with the 'God of the gaps'. Both concepts entangle us in logical and empirical contradictions. I shal come back to that.

21.According to Parsism, the good god Ahuramazda and his army of angels battle with the evil god Angra Mainyu and his army of demons. Humans are caught in the cross fire and opt for one or the other. At the final showdown (Armageddon), good triumphs over evil and the evil god, his demons and those who opted for him will be thrown into a fiery pool and destroyed for ever. Jewish post-exilic theology be thrown into a fiery pool and destroyed for ever. Jewish post-exilic theology resisted this dualism for some time. In Job 1-2, for instance, Satan is God's intelligence officer and public prosecutor, rather than an independent deity According to Revelation 12, he is thrown out of God's cabinet, while Christ is appointed the prime minister - a mythological depiction of the law-grace dialectic we find in Paul. Yet the idea of an evil counter-god was too alluring and too plausible not to have a powerful effect on later developments, such as reflected in the Book of Jubilees, as well as the Christian tradition. 
- Cosmic evolution progresses in levels of emergence characterised by exponential increases in complexity because of the combination of lower level components into new higher level wholes. If God is the Source of reality, God is the Source of all levels of emergence, including their respective characteristics, regularities and contingencies.

If that is true, our concept of God cannot confine itself to the level of personal intentions, decisions and actions, as if seemingly autonomous levels of emergence are not of God, but must cover such impersonal levels as well. It would be wrong, therefore, to attribute a tsunami to a personal decision and action of God, rather than to tectonic shifts in the earth's crust that follow the laws of nature, which are as much a means of God's creative action as decisions and actions are:

- God must be conceptualised as the Source of the whole of cosmic history from beginning to end. Whether a lifetime, an era, or cosmic history - every time span as such and as a whole comes from God, is sustained by God while it lasts and goes back to God when it ends. God cannot be confined to creation at the beginning (creatio ex nihilo), ongoing creation (creatio continua) or the envisioned consummation of the process at the end (a new creation).

What has been said so far constitutes the formal concept of God as the transcendent Source of a dynamically evolving reality. What defines the Christian faith in contrast to all other convictions, however, is the particular content of this concept, namely message of God's benevolent intentionality. This intentionality manifested itself in Christ as God's suffering transforming acceptance of the unacceptable. Where it surfaces, the vision of a positive outcome of cosmic history is based on the proclamation of God's unconditional love, rather than on any evidence or inevitability that the cosmic process will lead to a perfect world.

\section{Human uniqueness}

Humans are creatures among others. How do they fit into the hierarchy of emergences? Human nature cannot be reduced to the spiritual or personal level of emergence but covers the entire hierarchy. Humans are also fields, particles, atoms, organisms and nervous systems. At the quantum, physical and chemical levels, humans are not unique. At the biological level, human uniqueness is obvious: upright posture, free hands, opposing thumb, greater prefrontal cortex, different menstrual cycle, intercourse facing each other, etc. All this has often been described.

At the consciousness level, human uniqueness is constituted by, for instance, memory of the past, anticipation of the future, awareness of a greater space than the immediate environment, communication through symbolic representation (language), tool making, art, ritual, creativity in finding solutions, capacity to share cumulative experiences, interpretations and creations among successive generations (culture), etc. (Barrett 2015:32-33).
Higher animals display at least some rudimentary forms of such characteristics. Human uniqueness can therefore be conceptualised as the greater distance covered on a common, continuous, yet exponentially accelerating trajectory. A car driven in first gear will hardly overtake a car driven in fifth gear. However, 'distance' here means 'higher levels of emergence' ${ }^{22}$

An experiential realist approach will locate human uniqueness in theological terms at the most involved level of emergence, that is, the personal level. The human being is a creature that has the capacity to be in a personal relationship with an intuited ultimate Source and Destiny of reality, a participant in God's creative power and benevolent intentionality, and thus a representative of God on earth who is entrusted with the responsibility to rule over and care for other creatures. ${ }^{23}$

The range of reality experienced by humans is, therefore, more profound and more comprehensive in terms of space, time, power and regularity than that of higher animals. Much of what is impossible for higher animals has become possible for humans. Moreover, what is impossible for humans now may become possible in the future.

However, not everything is possible! Intentionality and agency can become effective only within the range of relative contingency discussed under the previous heading. With our limited resources of energy, we cannot move through a wall, but we can engage the energy of a bulldozer to do so. Again, even a bulldozer cannot lift us up to the sun or down to the centre of the earth. The operation of intentionality and agency is, therefore, strictly constrained.

\section{Overshoot}

Does human intentionality and agency succumb to these limitations? They notoriously do not! Eschatology is like an aeroplane overshooting the runway. From a scientific point of

22.The concept of 'deep incarnation' based on John 1:14 (the logos became flesh) to cover all 'flesh', that is, all living things and, beyond living things, cosmic reality as a whole (Gregersen 2015), indeed reflects the concept of the logos as the divine rationality underlying the cosmos as a whole according to the Stoa, which may have informed John 1. It also reflects emergence theory, which allows for a comprehensive view of immanent reality that includes the uniqueness of the human being. However, John's text applies the incarnation specifically to Jesus, the human being. Here, the issue is not the ontological character of God's presence in the world, but the particular character of this 'divine rationality', namely, 'grace the world, but the particular character of this 'divine rationality', namely, 'grace and truth', or self-giving love as manifest in Christ, or 'light' without darkness, as hohn 1:5 has it, and thus the real God who revealed 'himself' in the authentic
human being.

23.That is what the term 'image of God' in Genesis 1:26-30 originally referred to. It is found only here in the entire Old Testament. As the context shows, this metaphor refers to the unique dignity and responsibility of being put in charge of the other creatures as representatives of God. Note that the priestly creation story has no 'fall' into sin. In the New Testament, the metaphor is applied to Christ, the authentic human being, into whose image we are to be transformed (2 Cor 3:17-4:6; Eph 4:24). The term has since generated endless interpretations and speculations displaying an extraordinary range of polysemy. In terms of our topic, van Huyssteen's (2006) 'transversal' juxtaposition of the scientific concept of human uniqueness and the theological concept of the 'image of God' merits special mention. While I admire and envy the scholarship displayed in this remarkable work, I do not think that science and theology can interact as equal partners on the basis of a common part that determine the rationality of each of the two pursuits. Human uniqueness refers to ontologicanships. They are hardly comparable As far as the orgin and operation of mmanent reality is concerned, theology cannot possibly compete with scientific insight, while science has nothing to say about a creative and benevolent divine intentionality, which is the topic of theology. 
view, the most astounding facet of an eschatological vision is not the miraculous nature of its envisioned realisation, but the human capacity to conceive of such a vision.

This capacity seems to be a unique feature of the human being. A gemstone, a citrus tree, a slug or an impala are presumably not capable of developing the notion that the existing, certainly less-than-perfect world would be replaced with a new reality without limitations and hardships. At best, there is the urge to overcome pain and avoid death. So the very existence of eschatology is indeed a manifestation of human uniqueness!

Yet, the need to transcend the constraints of time and space, so typical for the human species, may be a version of the general trend for inanimate potentials to turn into realities and the urge of all living beings to survive and flourish within their inherent possibilities, albeit at a higher level of complexity than that reached even by higher animals. ${ }^{24}$ All higher living organisms display a frenzied mobilisation of all their available resources when their survival is threatened. Also in the human being, this urge is present at the biological level, but it also manifests itself at the spiritual level - and that as an eschatological overshoot.

Moreover, the fact that human visions and endeavours are capable of going beyond zero probability, thus imagining and probing the impossible in pursuit of the desirable suggests that this 'overshoot' is based not on probability but on validity: what ought to be is deemed valid, even if it is most unlikely to come about. Part of validity is the value of sound relationships. Does death have to sever all relationships? In biological terms, it does; in spiritual and social terms, we cannot accept the cessation of the significance of a deceased person for our life..$^{25}$

That is also what burial rituals are all about. They cannot undo the death of a person, but they can and do reaffirm the dignity of the deceased. In African traditions, for instance, it is fully recognised that the deceased lose their vitality and that the corpses rot in the grave. The ritual of 'bringing home the dead' is meant to affirm the belonging of the deceased persons to the clan and to enhance their authority as ancestors. ${ }^{26}$ Again the concept of validity seems to be a unique feature of the human species, yet again this might be a matter or degree, rather than principle.

\section{The human experience of time}

As the name implies, eschatology is all about 'the last things', or 'the end of the age', with the understanding that this will be followed by the 'age to come', or the 'coming kingdom of God'. So its original meaning refers to a future in time, if not beyond time. To see the phenomenon of overshoot in its

24.In my view, the tendency to go beyond the given is not only a result of what Polany calls 'tacit knowledge' generated in the context of the community, thus part of calls sto become in any new situation that is experienced as inadequate or unacceptable.

25.Jüngel interprets the horror of death as 'loss of relationships', which is overcome through faith in the crucified Christ with whom God has identified (1973:164-167).

26.More fully discussed in Nürnberger (2007:24-27). proper context, let us consider the typically human experience of time. There is a perceptual difference between physical time (measured in seconds, minutes, hours, etc.), experienced time (moving from the past through the present into the future) and existential time (expressed in terms of the quality of life in a particular situation and during a particular period: excitement versus routine, joy versus sadness, expectation versus fulfilment, etc.).

\section{Physical time}

Physical time is linear, continuous and irreversible. Its measurement in seconds and hours is a convenient but arbitrary imposition. In my view, experiential realism will not treat time as a fourth dimension similar to the three dimensions of space and that for the following reasons:

- Linear time manifests itself in the entropic process. ${ }^{27}$ There is no construction in time that does not presuppose deconstruction somewhere else in the environment.

- Causal sequences and networks imply linear time. Causal sequences never work in reverse gear. By implication, instances of contingency also imply time because they are a product of processes, rather than manifestations of 'eternity' however conceived.

- In my view, the reversibility of time, as assumed in physics, may be an illusion created by plotting time on a line in a geometric model, thus depicting it in terms of space. One can move up and down, left and right, forward and backward on a geometrical line, thus on a spatial dimension, but not in real time.

\section{Experienced time}

We can distinguish between factuality (what has become), actuality (what is in the process of becoming) and potentiality (what might become). The past is no more, the future is not yet; the present is the shifting boundary between past and future, without an extension of its own.

So time has no ontological status. ${ }^{28}$ Its reality lies in the uninterrupted process (the flow) of reality, just as the reality of matter lies in dynamic relationships within energy fields and energy conglomerations. It is in relation to this process that human intentionality and agency become operational: they are both motivated and constrained by factuality, geared to potentiality and effective in actuality.

\section{Existential time}

We experience the continuity of time through (1) the operation of cause and effect, and (2) memory, the ongoing flow of existence and anticipation. Continuity is then stabilised through cultural breaks such as routine, ritual, law and worldview. We also form abstractions of the 'essential', 'abiding' or 'eternal' from the flux of reality. Because

27. Linear time manifests itself in the entropic process, but it is not based on entropy, as often assumed, because entropy is subject to probability and variability both in velocity and intensity, time is not.

28.This phenomenon was first analysed by St Augustine in Book XI of his celebrated Confessiones. 
experiences and anticipations are recorded as synaptic structures in the 'geography' of our brains, our psyche is able to create the illusion of a 'time space' (or time span) with beginning, duration and end: a day, a lifetime, an era in human history or cosmic history as a whole.

This 'time space' can be filled in qualitatively different ways: celebration or mourning, exhilaration or boredom, novelty or routine. It can also be filled with beneficial and detrimental processes and pursuits. This fact makes humans accountable for their assumptions, intentions and behaviour. Accountable to whom or to what - only to oneself, or to the community, to society, to nature, to an ideal set of values and norms, to an ideology or a conviction?

On the one hand, the quest for what ought to become is occasioned by the immanent experience of what ought not to have become. ${ }^{29}$ The perception of the difference between what is and what ought to be is not limited, therefore, to what is possible or probable, but based on the perception of what is desirable, valid, true or authentic. As such, it relentlessly attacks the limits of what seems probable or possible.

On the other hand, we are intuitively aware of our own derivation, dependence, vulnerability, mortality, accountability and culpability. Our right of existence cannot be taken for granted - it can be questioned or forfeited. Ultimate accountability intuitively raises the question of ultimate authority - thus the transcendent Wherefrom and Whereto of our lives and reality as a whole - and the criteria of acceptability or authenticity as defined by this authority.

This is the fertile soil in which future expectations of all kinds have arisen in biblical times and virtually in all other cultures as well. However, these expectations vary widely both in content and quality. Are we reintegrated after our deaths into the ongoing lineage of our family as respected and authoritative ancestors? Do we sacrifice our lives for the greater glory of the fatherland or the classless society?

Do we enter into the endless cycle of rebirths in which our fate in the next life depends on our behaviour in our current life? Do we escape from the seemingly eternal cycle of suffering and enter Nirvana? Or do we follow the liberalcapitalist vision of unconstrained abundance, or the urge to enjoy immediate and unconstrained fun and pleasure that determines our postmodern culture to an alarming extent?

In terms of moral responsibility, I think it is reasonable to assume that humans should aim at optimal situations in which the survival and prosperity needs of all stakeholders are fulfilled to the extent that this fulfilment does not militate against the needs of other living creatures to survive and prosper. Such a vision of comprehensive optimal well-being for reality as a whole is afforded precisely by faith in God as

29.In scientific terms, the emotional experience of what ought not to have become and the vision of what ought to become is a function of the urge towards homeostasis within the body regulated by the hormone system. I owe this insight to Vincent (1990 [1986]:24-114).

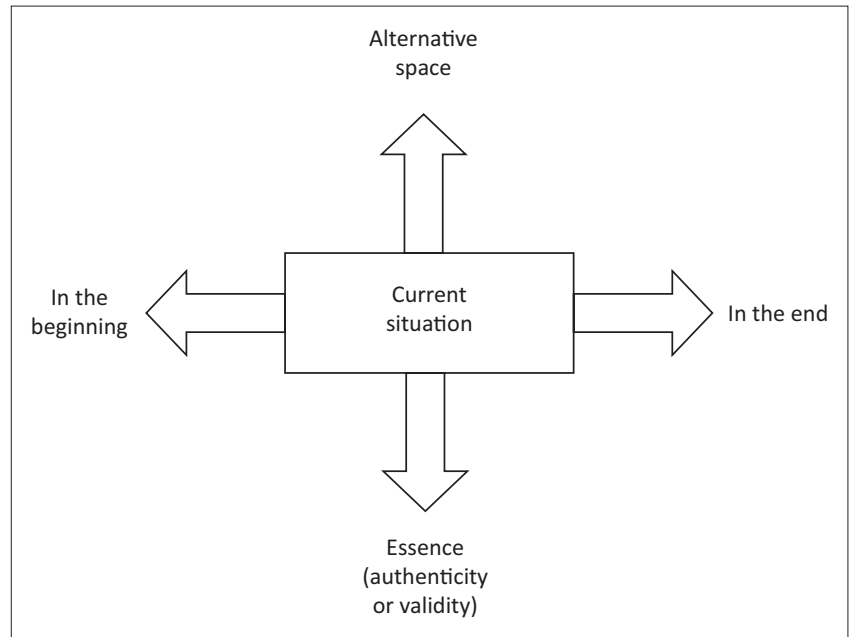

FIGURE 2: Four projections of what ought to be.

the ultimate Source and Destiny of reality as a whole as we find it in the biblical tradition.

In the biblical tradition, we find at least four different ways to conceptualise what ought to be: to the beginning (which was very good), to the end (which will be very good), to an alternative space (heaven above where everything is very good) and to the 'essence' of reality (which is meant to be very good) (see Figure 2). None of these projections are ubiquitous in the biblical tradition, or indeed essential. In fact, they can be used alternatively to express the same intention.

None of the four projections satisfies the scientific demand for evidence and that cannot be otherwise. Closer analysis of the texts reveals that these projections were never meant to be scientific findings of what has become, will become, exists elsewhere in the universe or the summary of essential characteristics, but expressions of what reality ought to have become, ought to be happening, ought to become or 'essentially' are. ${ }^{30}$

Projections of what ought to be are meant to give orientation to life. Because time always moves forward, never backward, 'upward' to an alternative space or 'downward' to an assumed essence, projections of what ought to become into the future are more realistic in terms of the realisation of what ought to become than the other three.

\section{The nature of biblical future expectations}

Experiential realism locates biblical future expectations at the level where they belong in terms of emergence theory, namely at the spiritual, rather than the physical, biological or sociopolitical levels. As a consequence, it asks what kind of theological concern might have led to particular visions, metaphors and conceptualisations of God's future found in

30.That they do not represent observation can easily be gathered from the fact that they deliberately use metaphors or mythological narratives that transcend given reality towards the currently unlikely or unattainable, yet desirable. Just look at the depiction of the new Jerusalem in Revelation 21, which deliberately uses completely unrealistic figments of the imagination to highlight the creative and redemptive power of God! 
the Bible, rather than speculate about the ontological shape such visions would take should they ever materialise.

Against this background, a historical-critical reading of the biblical tradition is imperative. As I see it, the 'Word of God' functioned as God's redemptive response to changing human worldview assumptions, needs, predicaments and depravities, rather than as an eternal truth falling ready-made from heaven. ${ }^{31}$ Some foundational redemptive experiences (whether historical or legendary) became classical. Beginning with rudimentary, ordinary and short-term needs and desires, they gained ever wider horizons and greater depths, involved greater potential powers, presupposed greater complexity and thus stretched the limits of probability.

On the basis of the proclamation of God's benevolence, faith assumed that God 'himself' would rejoice over 'his' redeemed creation because 'his' intentionality had come to fruition. Applying memories of redemptive events to ever new situations, the tradition evolved and differentiated in history. A familiar pattern would be: 'Yahweh, you acted redemptively for our fathers in their predicaments, gracefully do so again for us in our current predicaments!' This process is part of the exponential growth of complexity according to emergence theory, only at the level of human consciousness. ${ }^{32}$

During the process, some traditions became obsolete and were dropped; some were reinterpreted to fit current realities; some were further developed, some merged with congenial traditions. As the tradition responded to changing needs, situations and their interpretations, it differentiated into numerous sub-traditions. By the first millennium AD, a variety of traditions about God's future had emerged within Judaism, each with its own historical and situational roots in the context of changing world view assumptions. It is in this context that the nascent Christian faith has to be seen. Here are some of the more important:

- The continued blessedness of the clan/tribe/nation (survival).

- The restoration of the Davidic kingdom (national autonomy).

- The Day of the Lord (judgment over pagans and deviant Israelites).

- The Jewish empire (international politics).

- The Kingdom of God (priestly theocracy).

- The Son of Man in Daniel 7 (righteous versus beastly rule).

- The blessing of the Suffering Servant in Isaiah 53 (referring to the Babylonian exiles?).

- Resurrection to face judgment (post-exilic theodicy).

- The recreation of reality as a whole (apocalyptic theodicy).

- Death and resurrection to issue in a new creation (Paul).

Each of these traditions was occasioned by a particular situation of need and expected that this situation will be

31.For an extensive treatment of this view, see Nürnberger (2002).

32.Doing so they gained ever wider horizons (from clan to tribe, the nation, all nations, all cosmic powers, reality as a whole) and greater depths (progeny, land, national status, a new covenant, a new kind of heart, a new kind of body, a new kind of international politics, a new kind of natural world, a new heaven and earth). redeemed. Each evolved in history, branched out in various sub-traditions and remained controversial among Jewish and Christian believers. Most lost their relevance, disappeared or declined already during biblical history. ${ }^{33}$

In New Testament times, the evolution and differentiation of the tradition went apace. The transformation of existing reality into the Kingdom of God was believed to be tantalisingly imminent an expectation that Jesus and the early Paul shared. ${ }^{34}$ Further developments followed. When the expected parousia [second coming of Christ] did not materialise, eschatological perceptions were drastically modified in various directions. ${ }^{35}$

The evolution of future expectations was not arrested with the closure of the Canon. However, the translation of the gospel into Hellenistic patterns of thought shifted the emphasis from history to ontology and from apocalyptic to Platonic dualism. What mattered now was the fate of the 'immortal soul' after the death of the body. In early Catholicism, the institution of the church took the place of the kingdom of God. The transformation of the present age into 'the age to come' receded into the distant and largely irrelevant future.

We gather from these observations that (1) eschatology emerged and evolved fairly late in post-exilic Judaism in response to a particular series of situations and (2) it was open to radical reconceptualisations both in Judaism and Christianity. Apocalyptic dualism is, therefore, neither typical nor in fact essential for the nature of the biblical faith as such. Rather, it represents a particular contextualisation of the biblical faith in the power and benevolence of God among others. Moreover, it belongs to the 'spiritual' level of emergence, rather than the physical or biological. ${ }^{36}$

33 In the New Testament, many earlier forms are no longer significant (for instance the importance of male progeny, the Promised Land, the temple cult in Jerusalem, the return of the Jewish Diaspora). Alternatively they acquire a new meaning (for instance, Abraham as 'father of the faith', return to the land as ultimate 'rest' in instance, Abraham as 'father of the faith', Hebrews, the messianic king as the crucified yet glorified Christ, the 'new
Jerusalem').

4.According to the Synoptic sources, Jesus of Nazareth indeed proclaimed the imminence of the Kingdom of God, but he reinterpreted its content profoundly. It was again interpreted in different ways by different post-Easter traditions.

35.For Luke, the Christ-event marked the middle rather than the end of time (with the time of Israel before and the time of the Church after the event); Ephesians emphasises that Christ has already been enthroned above all cosmic powers; for John the decisive 'eschatological' event happens when a person is confronted with the living Christ and decides for or against him; Hebrews does not drop the idea of a last judgement, but emphasises that Christ has already been elevated to the status of the ultimate high priest.

36.'If it is impossible it cannot be true. But if it is true, it cannot be impossible (Russell 2008:304). This seemingly incontrovertible logic rests on an empirical criterion of truth. Similarly Peters et al. (2002): (science and theology share) the impetus to know what is real, to have confidence that what we know is rooted in what is true. Only knowledge of reality constitutes truth, and only truth can what is true. Only knowledge of reality constitutes truth, and only truth can quench the thirst that leads to research ( $p$. xiii). If truth is taken to be empirical
fact, doctrinal theology must be able to compete or cooperate with science at fact, doctrinal theology must be able to compete or cooperate with science at
the level of (past, contemporary or future) fact, or it cannot claim to be seeking or knowing the truth. But the two pursuits are incommensurate: (1) truth in science indeed refers to fact, although even that must be qualified, while in theology truth refers to authenticity or validity (the true God operating through the true human being). To ' $k$ now' in science means to be persuaded by evidence, while to 'know' in theology means to be persuaded by an authentic way of being human and existentially committed. The parable of the prodigal son is true, although the story has never happened and will never prodigal son is true, although the story has never happened and will never happen just as recorded. (2) The two concepts of truth belong to two different levels of emergence that cannot be collapsed into one. (3) The commitment of the two authors to the 'truth' of a particular strand of the biblical tradition betrays doctrinal positivism: If a future new creation actually arrives as God has promised, then its arrival will have to be due to divine intervention. The natural world will not evolve into a new creation as a result of God's continuous creation (Peters et al. 2002:xi). 


\section{Resurrection from the dead}

So much for the eschatological future of the world as a whole. What about the human being as part of this whole? For most of its history, the Israelite-Jewish tradition did not foresee any sort of life after death (Wilckens 1970:103f). ${ }^{37}$ Death meant that you are 'assembled to your fathers' (in the grave), that you enter the realm of the dead (Hebrew Sheol, Greek Hades), where there is no light, no life and no possibility to praise God. If resurrection from the dead belonged to the very essence of the biblical faith, it would be extremely odd that it was not expected in the foundational phases of its evolutionary history. The ancient Israelites were, after all, the most original believers in the biblical God. And they certainly had a very solid faith in God!

In fact, resurrection was a deduction from a more central concern of this faith: human righteousness and divine justice. As the Deueronomic idea that Israel suffered because of its sin lost its traction in post-exilic times, the question why those who did their best to keep the law suffered, while those who could not care less flourished became ever more pressing. The Book of Job is the prime example. God would not allow that the righteous forfeit their reward, while the sinners escape their punishment simply because they died. Death is no obstacle for the judgement of God, the Giver of life. So all people will rise from the dead to face judgement.

Enter the idea that death is the wages of sin! All people have to die because they all have sinned. Then we no longer rise to face judgement (which is already behind us) but to receive a new and authentic life in communion with God. Because it is no longer polluted by sin, it is no longer subject to death. According to Paul, Christ went through this fundamental transition, not because he was a sinner, but to open up the new authentic life in communion with God for those who find themselves in the clutches of sin. In the ritual of baptism we identify with the death of Christ and the new life of Christ. This takes us out of the mastery of the 'flesh' (sinful humanity) into the mastery of the 'Spirit' (life in fellowship with God). This is a life of self-giving love, thus a righteous life.

For Paul the transition is an existentially effective anticipation while we are still alive in this world, but it awaits its

\footnotetext{
(footnote 36 continues...)

No, the empirical world won't! But is that the only way that 'new creation' can be No, the empirstood?
understo

37.According to texts from Genesis 3:22 (the oldest) to Sirach 41:3-4 and 1 Timothy 6:16 (the latest), immortality is explicitly denied to humans by the biblical God. Sirach (= Ecclesiastes) is believed to have been written in the second last century before Christ. The first canonical instance of the notion of a judgement after death is found in Daniel 12:1-4, which is usually dated between 168 and 164 BC. Note that the promised reward is granted to persons for their wisdom and leading others to righteousness! It consists of shining like the sun and the stars 'forever'. This refers to status and significance rather than biological existence. Correspondingly, the threatened punishment does not consist of an eternity spent in the fires of hell, but of 'everlasting shame and contempt'. Both are a reflection of what ought to happen while we are alive. The author of Wisdom of Solomon seem what ought to happen while we are alive. The author of Wisdom of Solomon seems to have been the first sage who tried to offer a robust argument in support of resurrection (chapters 1-3). It was written later than Sirach, perhaps in the firstcentury $\mathrm{BC}$, and seemingly in response to Sirach. God had created all things, the author argues, so that they might exist; God did not create death! (1:13-14). However, even here the central concern is divine justice and human righteousness. Those who deny resurrection do so to get a free ticket to sin. Resurrection to face judgement was then embedded in the apocalyptic worldview.
}

ontological realisation when we die and rise physically to be where Christ is. Death and resurrection are part of the apocalyptic transition from this world to the world to come. However, in the Deutero-Paulines, and especially in the Johannine literature, the existential identification with Christ began to overshadow the apocalyptic future expectation. According to Ephesians 2, we are already elevated with Christ to the right hand of God; for John believers in Christ have already entered eternal (= authentic) life in fellowship with God.

Obviously this is a spiritual, rather than a biological renewal. But what about the resurrection of the body? For Paul the concept of the 'body' does not indicate a material, let alone a biological reality, but the concrete means to be in relationships with others. ${ }^{38}$ When Christ rose, he left his 'flesh' behind; he is now 'the Spirit'. But that does not mean that he is without a body. In contrast to Platonic or Gnostic assumptions, for Paul the body is of critical importance. The risen Christ is a new spiritual body. We are members of the 'Body of Christ'. Through our bodies we can relate not only to Christ but also to the prostitute. When we rise, we are given a new spiritual body, because without a body we could not be in relationships.

What about the 'resurrection' of Jesus? Obviously it was not the resuscitation of a corpse. What mattered for the disciples was the authority and the task to continue his work of proclaiming and enacting his message of God as a God of redeeming love. The risen Christ was the sending Christ. What mattered for the nascent Christian community was the continued presence of the living Christ in its midst. Responding to different congregational situations, the Easter message differentiated into the various sub-traditions we have today. Because they are situationally specific, they should not be harmonised with each other (Wilckens 1970:14-17).

But both these concerns are based on the reassurance that God identified 'himself' with the crucified Christ, thus with his message (Jüngel 1973:136-137). Through the elevation of Jesus to the status of the messianic representative of God, God confirmed the validity of his proclamation and enactment of the God of Israel as a God of unconditional, redeeming love by Jesus and, at the same time, opened up the new life of Christ for all people at all times and in all situations. That is the theological meaning of the 'resurrection of Jesus' irrespective of any empirical-historical or ontological questions concerning the nature of his risen body or his person. ${ }^{39}$

These observations confirm our initial impression that the core concern that led to the expectation of a resurrection from the dead was not the desire for longevity or an escape from the constraints of time, space, power and regularity, but the righteousness of God, who in Christ opens up an authentic

38.I owe this insight to lectures by Ernst Käsemann, a New Testament scholar of the 20th century.

39.See Nürnberger (2016:231-345) for details. Similarly, Wilckens (1970:159-160, 164-169). 
life in fellowship with God to all who avail themselves of the opportunity, while those who do not, exclude themselves.

\section{The function of a vision of what ought to become}

The concern for personal authenticity must be seen in the context of our life worlds. Experienced reality is highly ambivalent. There are the glories of life and the horrors of death. There is exuberant ecstasy and intolerable suffering. There is fulfilment and frustration. Hope, vision and determination are immensely important for human life.

They provide orientation and generate motivation. They go beyond the current situation towards what ought to become. They also transcend what seems probable or even possible at present. They emancipate the human being from enslavement by the realities and inevitabilities of the given situation and open up the future for unrealised potentialities. Under conditions of severe deprivation and frustration, future expectations may either collapse and lead to fatalism or transcend what seems probable and possible: in the end everything will be very good!

It is this freedom and this empowerment that makes it possible for humans to 'give their lives' for a greater cause than individual or collective self-interest. This greater cause can encompass different objects and horizons. ${ }^{40}$ The most comprehensive horizon is provided by faith in God because God is deemed the transcendent Source and Destiny of reality as a whole. Faith looks at reality from above, 'with the eyes of God' and our important but limited place in it. Faith identifies with, and is involved in, God's mastery and God's benevolence, rather than focusing on one's own resources, selfish interests and desires.

Faith trusts in the validity of its perceptions of what ought to become (based on God's intentionality as Destiny of reality) and the possibility that it might be realised (based on God's power as Source of reality). It shares God's vision of comprehensive optimal well-being, which translates into God's concern for any deficiency in well-being in any aspect of life. Faith in God can liberate, motivate and empower the human being to move with God into God's future. God's suffering transforming acceptance of the unacceptable (as manifest in the cross and elevation of Christ) involves us in the creative power and the redemptive benevolence of God.

\section{Does classical (apocalyptic) eschatology meet these expectations?}

Apocalyptic symbols and visions deliberately transcend the probable and possible to postulate God's creative power and God's benevolent intentionality. They represent an

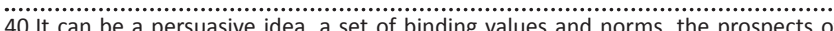
scientific and technological progress, the competitiveness and profitability of an scientific and technogical progress, the competitiveness and profitability of an enterprise, the extablishment group, loyalty to a fatherland, the urge to liberate an oppressed class or minority, dedication to the upliftment of impoverished people, rescue of abused animals, concern for the deteriorating natural environment or whatever. overshoot beyond the potentials of given reality towards a perfect world without entropy, injustice, suffering and death. As their Parsist precursors, apocalyptic visions are an expression of a defiant protest against what ought not to have become and the persistence of faith in a powerful and loving God who will throw in his weight to bring about what ought to be.

As in Parsism, the dualism between the current world and the world to come postulates that evil has no right to exist in this world, must be resisted and will be overcome. It is a message that has helped countless people to look beyond current frustrations, intolerably suffering, a meaningless fate and hopelessness. The message is clear: all these predicaments do not have the last word - God has the last word! And our God is for us and with us and not against us!

That certainly is the strength of the overshoot. However, a radical apocalyptic worldview suggests the replacement, rather than the transformation, of the existing world. Giving up on the existing world, it can sap the resolve to tackle actual problems at hand, live in an imaginary paradise and lead to injudicious decisions and actions.

Perfect situations are not only improbable but also impossible in the world we know. There is no evolution without entropy, no construction without deconstruction and no life without death. Therefore, the hope offered by the apocalyptic worldview is based on the placebo effect, rather than real potentials, or as Marxists have it, it is an opiate, rather than a cure.

In contrast, transformations happen all the time. They are based on the urge to survive and prosper, which is programmed into all living beings through evolution. Visions of a transformation towards a more acceptable future also go beyond what seems probable and possible under any given set of circumstances, but they give direction for our thought, intentionality and agency and empower us to move towards the envisioned situation with courage and determination, even where the way forward seems to be blocked. Here we find at least four possible perceptions:

1. If what has become is taken to be roughly identical with what ought to become, or closer to the latter than any perceived alternative, no change is needed, envisaged or desired. This stance characterises traditionalism and conservatism of all kinds.

2. What has become must be changed into what ought to become. This perceived imperative leads to activism, or in situations of powerlessness, to ardent prayer for change.

3. What has become is beyond repair and should be replaced with what ought to become. Here we enter into the sphere of wishful thinking, fantasy, utopia and science fiction.

4. What has become should not only be replaced with what ought to become, but will be replaced with what ought to become because God wills it and God's will cannot be thwarted. 
This is the assumption of eschatology proper, which postulates that there will be a definite end to existing reality to make way for an altogether new reality. And yet there must be continuity with the identity of the old world, otherwise the expectation would be pointless. To evaluate this position, we have to draw out the implications of the experiential concept of God as sketched at the beginning of this essay.

\section{Critique of a few assumptions legitimating apocalyptic eschatology Divine agency and eschatology}

How tenable is the assumption that God can and will bring the current world to an end and create an altogether new world free from the constraints of time, space, power and regularity, thus also free from injustice, depravity, error, suffering and death?

The biblical concept of God is experiential. God is perceived to be the personal Source of all aspects of actually existing reality: the inexorable paths of the heavenly bodies, the sequence of the seasons, the vitality of living creatures, the motivations of human beings and the rise and fall of empires. This raises an inescapable question: can a benevolent and allpowerful God not eradicate evil, whether moral, social or natural, once and for all with one fell decree?

If that were the case, it would be incomprehensible why 'he' has not done so a very long time ago. This is the perennial question of theodicy, a question that has haunted the biblical faith from its very beginning and has caused countless believers to become disoriented and disillusioned, if not to abandon their faith in God altogether. The reason for this impasse was a pre-scientific worldview, which naively over-personified the ultimate Source and Destiny of reality.

The theory of emergence suggests that God indeed became a person for humans because humans are persons, but as the Source and Destiny of reality as a whole, thus of the entire hierarchy of emergences, God must be much more than a person, just as human beings (the model from which anthropomorphic metaphors for God have been derived) are much more than persons: they are also fields, quanta, molecules, organisms and synaptic networks.

Intentionality and agency belong to the personal level of emergence, but this level presupposes the infrastructure of all lower levels of emergence - which are also of God! In the biblical tradition, God is praised for the stability of the sky, the regularity of the heavenly bodies and the reliability of the seasons. In fact, for the creation narrative of Genesis 1 'creation' means that God overcomes the power of chaos through installing dependable structures and regularities within which life can flourish. ${ }^{41}$

41.Ancient Israel shared the assumption of a 'cosmic order' comprising the natura order, the social order and the moral order, with much of the Ancient Near East (Schmid 1968).
Does faith in God the Creator not imply the unconstrained freedom of God to do as 'he' pleases whenever and wherever 'he' pleases? No, it does not! Seen against the background of what actually happens in the reality that God is creating, the idea of unconstrained divine freedom is pure speculation or wishful thinking. According to the biblical faith, God is the Lord and Creator of the existing universe, which is in fact subject to regularities. Contingencies are inextricably embedded in the processes following these regularities.

The laws of nature are God's laws and as God's laws they are valid. Moreover, these laws are necessary for the existence and functioning of the universe. They cannot simply be suspended without creating massive mayhem. If the law of gravity that keeps our feet on the ground would be suspended for a single second, we would all fly into outer space. ${ }^{42}$ If these regularities are indispensable for the functioning of the cosmic process, they can be deemed a manifestation of God's benevolence as indeed they are in the biblical tradition.

\section{Divine omnipotence and eschatology}

Is God then not omnipotent after all? Indeed God is. But in the Bible God is proclaimed as the Power behind actually occurring events thus, by implication, of the energy that underlies all these processes and the regularities and contingencies according to which they function. God is omnipotent in the sense that 'he' is the Source and thus the Lord of all power including the way it operates. From this proclamation follows a pastoral reassurance: whatever may happen, God is still in charge and God is uncompromisingly committed to our well-being. This is an inductive, experiential concept of omnipotence. It does not exclude a less than perfect outcome.

Platonic thought, in contrast, abstracts from existence to essence, from time to eternity, from space to universality, from energy relations far from equilibrium to harmony, from the imperfect to the perfect. ${ }^{43}$ This abstraction is then idealised: actual, constrained power as we experience it becomes absolute, unconstrained power. If God is really God, the argument goes, 'he' cannot be subject to any constraints of time, space, energy and regularity, but is free to call into being whatever he likes, whenever he likes, at whatever cost.

\footnotetext{
42.To use a biblical example, if the sun had indeed come to a standstill at Gibeon so that the Israelites could defeat their enemies (Jos 10:12), this would have meant that the earth, rotating at an equatorial speed of $1674.4 \mathrm{~km} / \mathrm{h}$, came to a sudden halt- which would have caused the mother of all tsunamis, sweeping away the Israelites together with their enemies and all life on sweeping away the Israelites together with their enemies and all life on what happens when we overlook the literary character of ancient biblical narratives.

43.Protestant Orthodoxy of the 17th century, after claiming that its concept of God was 'also mainly derived from revelation' in Scripture and that "with the knowledge thus derived we must be satisfied', defines God as 'an Infinite Spiritual Essence' (Schmid [1899' 1961:111-112). Where do you find that in Scriptures? From there it deduces attributes of God by ascribing to God 'all the perfections which we can discover in His creatures' and 'removing ... all imperfections which we observe in discover in His creatures' and removing ... all imperfections which we observe in creatures' (p. 117). Among these attributes we find 'immutability' (liable to no change - 'the absolute negation of all motion'), and yet also 'life' ('by which the divine essence always shows itself active' (pp. 118-119), creativity, etc. It is obvious that this idea is not based on experience, or biblical texts; it is, rather, an idealise abstraction from concrete reality, typical for the Platonic heritage of classical theology. There is nothing in our experience of reality or in the Scriptures that could substantiate such a claim.
} 
According to this philosophical tradition, God is pure intentionality, pure agency, actus purus (a medieval term derived from Aristotle), thus pure personhood without the infrastructure of lower levels of emergence. Again, this is a deductive, metaphysical concept of omnipotence, in fact an idealised abstraction from actual experiences of power. It may appeal to the naive believer, but it cannot claim to apply to the creative power and the benevolent intentionality that we actually experience. And it causes the insoluble puzzlement of theodicy mentioned above, rather than the reassurance of faith. ${ }^{44}$

If this idealised abstraction is then sought and found in the Bible and attributed the status of a revealed immutable truth, the eschatological visions found in the Bible and in subsequent doctrinal pronouncements are no longer seen as dynamic redemptive responses to situational needs and predicaments, but as static and eternal truths that cannot be questioned without giving up on the biblical faith.

If theology follows this path, it cannot help but compete with modern science in explaining the world, rather than entering into a complementary relationship with science. ${ }^{45}$ As we have seen, this cannot be upheld even on purely exegetical grounds.

\section{Eternity and eschatology}

The approach of experiential realism finds it difficult to attach any clear meaning to the concept of eternity. Hebrew does not even possess a word for eternity. Olam, usually translated as 'eternal' refers to a time span or age. It can be the distant past, the distant future or ongoing history. There is a keen understanding that an age has a beginning and an end: natural processes are reliable 'as long as the earth exists' (Gen 8:22).

It usually refers to the unfailing commitment of Yahweh to Israel: just as he had called, liberated and blessed his people during the time of the fathers, so he will act on their behalf now and in the future. The correct translation of Psalm 90:2 (meolam ad olam) is 'from age to age', because 'from eternity to eternity' does not make sense. The Parsist and apocalyptic dualisms between this age and the age to come insist that evil has no right to exist, but not that time as such is evil.

The Greek word aion also refers to an age. However, in Platonic thought it acquired the meaning of timelessness. The constraints of time, space, energy differentials and regularity were seen as inhibiting, fleeting, unpredictable, non-essential and unworthy of the divine. In this sense, timelessness is an idealised abstraction from time, just as the concepts of

44.It is also not possible to marry ontology with history. As a concept of eternity that 'is a richer concept of temporality than timelessness or unending time', Russell tries to envision a 'co-presence of all events', an 'inhomogeneous tempora ontology' and an event that has duration, that is, 'temporal thickness' (2008:313). Such metaphysical constructs are, in my opinion, implausible 'square circles' that have no evidential basis in experienced reality and will hardly persuade hardcore
empirical scientists.

45.See my distinction between the real God and the true God, as well as the real human being and the true human being, in Nürnberger (2013:chapters 7-9). immutability, universality, omnipotence, omnipresence and omniscience are idealised abstractions from the actual experience of reality.

That is the approach theology has inherited from Greek philosophy, rather than the Bible. It may have been useful in contextualising the message in a Hellenistic world, but it came at the price! The postulated timelessness of God is both unintelligible and incongruous with the biblical tradition. Where there is no time, there is no life - whether on earth or 'in heaven' - because life is an ongoing process. ${ }^{46}$

The concept has since displayed an astonishing polysemy: timelessness, never ending time, the ever present moment, the break-in of divine reality into the human world 'vertically from above', authentic existence, the Kingdom of God, the very character of the divine, etc. It has become a vague but handy expression of transcendence because it no longer has to be defined. It has also become a play ball of metaphysical speculations, such as the simultaneity of past, present and future in a continuing flow of time. In experiential realist terms, only the past is 'eternal' because what has happened can never again be altered or erased from cosmic history. But the past is also no longer real! ${ }^{47}$

\section{Contingency and eschatology}

The view that reality as a whole, and thus in all its manifestations, is contingent has recently been used to underpin the theological assumption that an all-powerful Creator God can transform existing reality into a new reality without entropy, suffering and death, including the transformation of a corpse into an immortal body. ${ }^{48}$

In my view, this is a problematic assumption, whether in scientific or theological terms. In theological terms, God does not need contingency to act creatively. God creates as much through regularities as he creates through contingencies. That has already been spelt out.

46. Nothing could be more otherworldly in experiential terms and disconcerting for faith as the message that God has never changed and cannot change. This idea has again morphed into the message that everything has been foreknown, predetermined or predestined 'from eternity'. That is not only unintelligible (where there is no time, there is no 'pre') but also inimical to the gospel, which reassures us of God's unconditional love. This wayward series of deductions from an idealised abstraction has proved to be one of the greatest sources of agony for serious believers.

47.This has immediate repercussions for human death Speaking of the Old Testament, Jüngel says: 'The human being is, when "he" died, only what he was. "He" will no longer become something and in this sense no longer exist' $(1973: 145)$. However, if we are in communion with God, our lived life is 'eternalised' in God's own eternity. 'Our lives will be kept save in God's life' ( $p$. 152). Jüngel quotes Karl Barth (Church Dogmatics, III/2, page $770 \mathrm{f}$ - - German edition) as follows: 'The human being as such has no beyond, and does not need one, because God is 'his' beyond ... The human being as such is this-worldly and therefore mortal and dying and will one day only have been, just as "he" has once not been' (1973:153-154, [author's own translation]). All this presupposes the assumption of an 'ontology' of divine eternity, as opposed to nothingness plain and simple.

48.The discussion about contingency is involved. For a useful typology, see Russell (2008:36-38). Whether applied to creation out of nothing (creatio ex nihilo), to ongoing creation (creatio continua) or the laws of nature (which he calls 'nomological' contingency), the thrust of the argument is not only that all creatures are dependent but also that nothing that exists and happens exists and happens necessarily. The implication is that God's agency is not subject to regularities and necessarily. The implication is that God's agency is not subject to regularities and
constraints. I do not think that this conclusion is tenable whether in experiential realist or biblical terms. 
In scientific terms, it may be possible (yet not certain) that the big bang and cosmic evolution could just as well not have happened; that the fine tuning of the universe could just as well have been different; that the laws of nature could just as well not have been in operation; that mutations making the emergence of new species in changed environmental niches possible could just as well not have happened.

But all that does not imply that there is no regularity in the universe we experience; or that the regularity that does exist can simply be suspended; or that situations of contingency do not owe their realisation to causal sequences in the past; or that such situations can give rise to an unconstrained sequence of events; or that the 'first instantiation' of a 'new' law of nature does not follow from its antecedents, so that a completely different law of nature could have emerged under the same circumstances. ${ }^{49}$

If God wanted to create a new reality that is not subject to time, space, energy, regularity, embedded contingency and death, he would have to start again at the big bang with something quite different from the big bang. To use a metaphor: an engineer is free to design a motor car, an aeroplane or a rocket, but if he wants to design a car, he will have to follow the logic of his design. He cannot assume that a car built for the roads will suddenly be able to fly off into the air.

\section{Our task as theologians}

Apocalyptic eschatology is not foundational for the biblical faith, no longer persuasive in theological terms, nor tenable in scientific terms. This includes the idea of a resurrection of the (biological) body. Eschatology, whether in cosmic or individual terms, has been a late development in post-exilic Jewish thought as a contextual response to a particular impasse. It represents only one branch of this thought among others; it was never universally accepted in Judaism..$^{50}$

It would seem then that this kind of eschatology does not belong to the essence of the biblical message, but represents a particular contextualisation of this message. As such, it no longer fits our own context. Therefore, it must not be absolutised as eternal truth. We must do for our times, what the biblical authors did for theirs: proclaim the creative power and redeeming love of God as a response to

49.It is difficult to assume that the resurrection of jesus was based on the "first instantiation' of a new' law of nature' that will then determine the new creation
(Russell 2008:309-310), because this would imply that the envisaged new reality is (Russell 2008:309-310), because this would imply that the envisaged new reality is
powered by an energy that is not derived from the entropic process, that reality is powered by an energy that is not derived from the entropic process, that reality is
no longer subject to constraints of space and time and that life no longer ends in death. To achieve such a new reality, God would have to begin all over again with the big bang, laying down a new series of initial conditions. The question is not whether such a new reality is possible, or even imaginable; the question is what concern motivates a scientist and theologian to develop such a vision.

50.The expectation of the Kingdom of God indeed seems to have determined the faith and proclamation of Jesus and the nascent Christian community, yet it did so in a decisively transformed form. It was further modified already in New Testament times when the expected transformation of the universe did not materialise. When the Christian fith the Christian faith moved into the Hellenistic world, the apocalyptic dualism between this age and the age to come receded into the far future, while the Platonic dualism between matter and spirit, and the Stoic dualism between logos and 'flesh', determined the discussion. Not the imminent new universe commanded all interest, as in early Christianity, but the institution of the church and the precarious fate of the soul after death. the predicaments and worldview assumptions of our contemporaries.

From an experiential realist point of view, I suggest that we reconceptualise eschatology as God's vision of comprehensive optimal well-being. Note that I say 'optimal' rather than 'perfect'. It suggests a balance between the needs of all 'stakeholders'. As far as we know, a perfect world is not just unlikely, but impossible, because reality is in constant flux. Perfection implies a static (ontological) rather than a dynamic (historical) situation. ${ }^{51}$ And that can only be imagined as an idealised abstraction.

God's vision of comprehensive optimal well-being, in contrast, translates into God's concern (thus our concern) for any deficiency in well-being in any aspect of life. It gives us direction and galvanises us into action. The ambiguity of reality does not question the assumption of a benevolent God, but calls for it. With God we move towards life and against death, towards construction against destruction, towards evolution against entropy.

There is no guarantee that this committed involvement will lead to a perfect world. It is the direction of the pilgrimage that defines authenticity, rather than the end result. Where our powers fail, we trust that our limitations are not God's limitations, that the spectrum of possible futures is infinitely greater than we are aware of and that God has more means and agents at 'his' disposal than we have.

God's vision resembles a horizon that moves on as we approach it, opening up ever new vistas, challenges and opportunities. It motivates and empowers us to move with God into the future, rather than waiting for God to act. Or rather, it motivates us to allow God to use our potentialities to move towards his vision. A vision is not a prediction, but a lure to act responsibly and lovingly in the direction of comprehensive optimal well-being.

Such a vision ceases to be 'eschatology' in the sense of a dramatic end to the current world and an entirely new creation. ${ }^{52}$ God's vision drives an ongoing process that has a direction rather than an end. Yet we have to accept the probability that, like everything within reality, the universe as a whole has had a beginning and will have an end. It is subject to built-in and essential constraints. All processes presuppose the transformation of potent energy into spent energy (entropy). According to current scientific insight, the universe may eventually run out of potent energy. We also know that all life ends in death. There is no way we can escape this conclusion.

51.In a perfect situation, any movement would be a movement away from perfection There would be no intentionality or agency, no way of looking forward to anything no joy of having accomplished anything no cooperation with others to reach goals, no solidarity with those who are less blessed and no actual and active love.

52.The continued use of the term 'the last things' creates confusion if it is meant to refer to the transformation of an inauthentic to an authentic existence and life world at the end of a particular time span. Theologians must dare to abandon traditional concepts that no longer covey the intended meaning, just as the sciences do. 
These considerations lead us to the very core of the Christian message: God's vision is powered by God's suffering, transforming acceptance of the unacceptable as manifest in the cross and elevation of Christ. This stands in marked contrast to the idea of God's dogged insistence on flawless perfection. Using anthropomorphic metaphors, we can say that the transience of everything that exists and happens is the cost God is prepared to bear (and we have to bear) for having the kind of reality of which we are a part in the first place and, as far as we know, there is no other.

If God is the transcendent Source and Destiny of the very reality we experience and the sciences explore, the cross of Christ, with which God identified, has been a paradigmatic event with cosmic significance: God ceaselessly sacrifices parts of 'his' creation so that other parts can emerge, evolve and flourish. ${ }^{53}$ We are privileged to share this sacrificial love, 'bearing the cross of Christ' for the sake of God's creation, rather than be motivated by our rather selfish desire for longevity or perfection. It is obvious that this consideration is of the utmost importance when considering the economicecological crises into which we seem to be drifting and which will demand extraordinary sacrifices in the future.

\section{Acknowledgements Competing interests}

The author declares that he has no financial or personal relationships which may have inappropriately influenced him in writing this article.

53.From a very different (existentialist) vantage point, Jüngel says: "God is in no way the one who cannot possibly suffer, but the one who can suffer endlessly and who, for the sake of his love, does suffer endlessly' (1973:143).

\section{References}

Barrett, P., 2015, 'The emergence of imagination and altruism in human evolution: Key elements of a new-style natural theology', Journal of Theology for Southern Africa, 153, November 2015, 29-45.

Clayton, P., 2004, Mind and emergence: From quantum to consciousness, Oxford University Press, Oxford.

Gregersen, N.H. (ed.), 2015, Incarnation: On the scope and depth of Christology, Fortress, Philadelphia, PA

Jüngel, E., 1973, Tod, Kreuz-Verlag, Stuttgart.

Hawking, S. \& Mlodinow, L., 2010, The grand design: New answers to the ultimate questions of life, Bantam Press, London.

Kauffman, S., 1995, At home in the universe: The search for the laws of selforganization and complexity, Oxford University Press, Oxford.

Kauffman, S., 2015, 'From physics to semiotics', in D. Evers et al. (eds.), Issues in science and theology: What is life?, Springer, London.

Nürnberger, K., 2002, Theology of the Biblical Witness: An evolutionary approach, Lit-Verlag, Münster.

Nürnberger, K., 2007, The living dead and the living God: Christ and the ancestors in a changing Africa, Cluster Publications, Pietermaritzburg.

Nürnberger, K., 2012, 'Eschatology and entropy: An alternative to Robert John Russell's proposal', Zygon 47(4), 970-996.

Nürnberger, K., 2013, Informed by science, involved by Christ: How science can update, enrich and empower the Christian faith, Xlibris Corporation, London.

Nürnberger, K., 2016, Faith in Christ today: Invitation to Systematic Theology. Volume II: Involved in God's project, Xlibris Publishing, London.

Peacocke, A., 2007, All that is: A naturalistic faith for the twenty-first century, Fortress Press, Philadelphia, PA (edited by Philip Clayton).

Peters, T., Russell, R.B. \& Welker, M., 2002, Resurrection: Theological and scientific assessments, Willian B Eerdmans, Grand Rapids, MI.

Russell, R.J., 2008, Cosmology: From Alpha to Omega: The creative mutual interaction of theology and science, Fortress Press, Minneapolis, MN.

Schmid, H., 1961 [1899], The doctrinal theology of the Evangelical Lutheran Church, Augsburg Publishing House, Minneapolis, MN.

Schmid, H.H., 1968, Gerechtigkeit als Weltordnung, JCB Mohr, Tübingen.

Van Huyssteen, J.W., 2006, Alone in the World? Human uniqueness in science and theology, The Gifford Lectures, William B Eerdmans, Grand Rapids, MI.

Vincent, J.-D., 1990 [1986], Biologie des Begehrens: Wie Gefühle entstehen. Rowohlt, Hamburg. (English version: 1990, The biology of emotions).

Wilckens, U., 1970, Auferstehung: Das biblische Auferstehungszeugnis historisch untersucht und erklärt, Kreuz-Verlag, Stuttgart.

Zahrnt, H., 1966 [1969], Die Sache mit Gott: Die Protestantische Theologie im 20. Jahrhundert, Piper \& Co, Munich. (English version: 1969: The question of God: Protestant theology in the twentieth century, Collins, London). 